by the hydrazone method gave values of 68 per cent for the Anacystis extract and 65 per cent for the crystalline aldolase of the expected triose from fructose diphosphate added by weight. The above data indicate a ratio of two triose per one fructose diphosphate split and support the assumption that the enzyme activity seen is that of aldolase.

All enzyme activity determinations were made with freshly made preparations. The aldolase activities from all three blue-green algae were very reproducible, with no instance of an inactive preparation. Stability of the crude enzyme from Anacystis was not examined except for an overnight storage of $4^{\circ} \mathrm{C}$, when the loss of activity was less than 5 per cent.

There is nothing in the observations made during this work to suggest why both Richter and Fewson failed to find aldolase activity with Anacystis, or with other bluegreen algae. The data presented here support the thesis that aldolase is present in blue-green algae and in sufficient amount to allow its participation in photosynthesis and also possibly in a glycolytic pathway of carbohydrate metabolism. However, the facile demonstration in blue-green algae of certain of the enzymes of the hexose monophosphate pathway (refs. 1 and 2 , and unpublished observations) suggests the operation of this pathway also and no decision as to the relative importance of the two pathways can be made at this time.

This work was supported by National Science Founda. tion grant 19198.

Institute of Marine Science, Port Aransas, Texas.

${ }^{1}$ Richter, G., Naturwissenschaften, 46, 404 (1959).

${ }^{2}$ Fewson, C. A., Al-Hafidh, M., and Gibbs, M., Plant Physiol., 37, 402 (1962).

${ }^{3}$ Van Baalen, C., and Marler, J. E., J. Gen. Microbiol., 32, 457 (1963).

4 Kratz, W. A., and Myers, J., Amer. J. Botany, 42, 282 (1955).

${ }_{5}^{5}$ Provasoli, L., McLaughlin, J. J. A., and Droop, M. R., Arch. Mikrobiol. 25, 292 (1957)

- Van Baalen, C., Botanica Marina, 4, 129 (1962).

'Beck, W. S., in Methods in Enzymology, 3, 291 (Academic Press, New York, 1957).

${ }^{8}$ Peanasky, R. J., and Lardy, H. A., J. Biol. Chem., 283, 365 (1958).

' Taussky, H. H., and Shorr, E., J. Biol. Chem., 202, 675 (1953). ${ }^{10}$ Lowry, O. H., Rosebrough, N. J., Farr, A. L., and Randall, R. J., J. Biol.
Chem., 193,265 (1951).

1 12utter, W. J., in The Enzymes, 5, 341 (Academie Press, New York, 1961).

${ }^{12}$ Bard, R. C., and Gunsalus, I. C., J. Bacteriol., 59, 387 (1950).

\section{Aldolase in Anacystis nidulans and Rhodopseudomonas spheroides}

Extracts of some Cyanophyceae ${ }^{1-3}$, and Rhodopseudomonas spheroides ${ }^{2,4}$ appear to lack significant amounts of fructose-1,6-diphosphate aldolase. These findings were unexpected, at least with respect to the blue-green organisms, for two groups of authors ${ }^{5,6}$ found that the distribution of ${ }^{14} \mathrm{C}$ in the products formed during photosynthesis was similar to that obtained with Chlorella, an alga which contains aldolase. This manuscript is concerned with the partial characterization of aldolase in Anacystis nidulans and $R$. spheroides. A similar enzyme was also detected in extracts of Tolypothrix tenuis and Anabaenopsis sp.

A. nidulans was grown autotrophically in modium ' $\mathrm{C}$ ' (Kratz and Myers') and $R$. spheroides was cultured as described by Szymona and Doudoroff ${ }^{4}$. The cells were suspended at a concentration of $0.5 \mathrm{~g}$ wet weight per $10 \mathrm{ml}$. of $0.1 \mathrm{M}$ tris, $p \mathrm{H} 7 \cdot 5$, and were disrupted in a Mickle apparatus at $4^{\circ}$ for $10 \mathrm{~min}$ under an atmosphere of air or $\mathrm{N}_{2}$. Aldolase was assayed by the hydrazone procedure ${ }^{8}$ in an environment similar to the one in which the cells were broken.

The basic activity was markedly stimulated by $\mathrm{N}_{2}$ cysteine or $\mathrm{Fe}^{++}$when added as ferrous sulphate or as ferrous ammonium sulphate (Table 1). Inhibition by ferric ammonium sulphate could be relieved by cysteine.
Table 1. Aldolase AssaYs of $R$. spheroides AND A. nidulans $\mu$ moles FDP split/mg protein/h $\begin{array}{ccccc}\text { Growth } & \text { Control cysteine } & \mathrm{Fe}^{++} & \begin{array}{c}\text { Cysteine } \\ \text { and } \mathrm{Fe}^{++}\end{array}\end{array}$ Air $N_{2}$ Air $N_{3}$ Air $N_{8}$ Air $N_{8}$ $\begin{array}{llllllllll}\text { glucose } & 0.2 & 0 & 0.5 & 1.3 & 0.1 & 0.7 & 0.4 & 0.5\end{array}$ $\begin{array}{lllllllllr} & \text { glucose } & \mathbf{1} \cdot 0 & 0.8 & 3.0 & 8.8 & 3.6 & 4.7 & 5.0 & 9.9 \\ \text { A. nidulans } & \text { Light, } 1 \% \mathrm{CO}_{2} & 0.5 & 0.3 & 3.6 & 17.0 & 3.4 & 11.4 & \mathbf{5} .5 & 13.0\end{array}$ In a final volume of $2.5 \mathrm{ml}$. the complete reaction mixture consisted of: $100 \mu$ moles tris buffer, $140 \mu$ moles hydrazine sulphate, $20 \mu$ moles cysteine $20 \mu$ moles ferrous ammonium sulphate; extract containing 0.2 to $0.4 \mathrm{mg}$ protein, and $5 \mu$ moles fructose-1,6-diphosphate. The flnal $p \mathrm{H}$ was $7 \cdot 5$ Actetic acid. Further details are given in ref. 8 .

BAL was able to replace cysteine while reduced glutathione was inactive. Frozen extracts prepared under air or $\mathrm{N}_{2}$ and kept in the presence of cysteine lost roughly half their activity in $24 \mathrm{~h}$. Rapid removal of cell debris after rupture of the cells was essential for obtaining high activity; this may account for the failure of others to detect the enzyme. $p$-Chloromercuribenzoate $\left(10^{-4} \mathrm{M}\right)$, $o$-phenanthroline $\left(10^{-4} \mathrm{M}\right)$, and $\alpha$ - $\alpha^{1}$-dipyridyl $\left(10^{-4} \mathrm{M}\right)$ were effective inhibitors. Iodoacetamide $\left(10^{-4} \mathrm{M}\right)$ was ineffective.

The maximal activities obtained with $A$. nidulans and $R$. spheroides were more or less equal to those reported for higher plants ${ }^{3}$ and for photosynthetic bacteria ${ }^{9}$. These findings indicate that aldolase of the Cyanophyceae and photosynthetic bacteria, in contrast to that of higher plants and green alga $\Theta^{3}$, is a metallo-sulphydryl enzyme, or type II according to the classification of Rutter ${ }^{10}$.

This investigation was aided by grants from the National Science Foundation and the U.S. Air Force through the Air Force Office of Scientific Research of the Air Research and Development Command.

James M. WiLlard *

MARVIN SCHULMAN Martin GibBs

Department of Biology, Brandeis University,

Waltham, Massachusetts.

* Predoctoral fellow of the National Institutes of Health.

${ }^{1}$ Richter, G., Naturwiss., 46, 604 (1959).

2 Richter, G., Biochim. Biophys. Acta, 48, 606 (1961).

${ }^{3}$ Fewson, C. A., Al-Hafidh, M., and Gibbs, M., Plant Physiol., 37, 402 (1962).

${ }^{4}$ Szymona, M., and Doudoroff, M., J. Gen. Microbiol., 22, 167 (1960).

${ }^{5}$ Kandler, O., Naturviss, 48, 604 (1961).

' Kindel, P. K., and Gibbs, M., Nature, 200, 260 (1963).

' Kratz, W. Z., and Myers, J., Amer. J. Bot., 42, 282 (1954).

${ }^{8}$ Sibley, J. A., and Lehninger, A. L., J. Biol. Chem., 177, 859 (1949).

'Fuller, R. C., Smillie, R. M., Sisler, E. C., and Kornberg, H. L., J. Biol. Chem., 236, 2140 (1961).

${ }^{10}$ Rutter, W. J., in The Enzymes, edit. by Boyer, P. D., Lardy, H. A., and Myrbäck, K. ., V, 341 (Academic Press, New York, 1961).

\section{Lack of Uptake and Oxidation of Chylo- micron Triglyceride to Carbon Dioxide and Ketone Bodies by the Perfused Rat Liver}

FATTY acids concerned with supplying the caloric requirements of the body are transported in the blood primarily as free fatty acids (FFA) or as triglyceride fatty acids (TGFA). The liver is thought to play a central part in the metabolism of both chemical forms ${ }^{1}$. Investigations have shown that injected FFA labelled with carbon-14 are taken up by the liver ${ }^{2}$, where they may be catabolized by $\beta$-oxidation to carbon dioxide or ketone bodies $^{3}$, or be synthesized into TGFA, which give rise to the very-low-density $(d<1 \cdot 006)$ lipoproteins of the plasma $^{2}$. Chylomicron-TGFA labelled with carbon-14 are also reported to be taken up by the liver ${ }^{4}$ and to be oxidized to carbon dioxide or ketone bodies in certain experimental conditions ${ }^{3}$. However, previous experiments in vivo have demonstrated that the magnitude of ketogenesis in fat-fed rats is not related to the extent of the influx of chylomicrons ${ }^{5}$ but rather to the level of circulating FFA $^{6}$. In perfused livers from fasted rats, Morris ${ }^{3}$ found that 75 per cent of chylomicron-TGFA were removed 